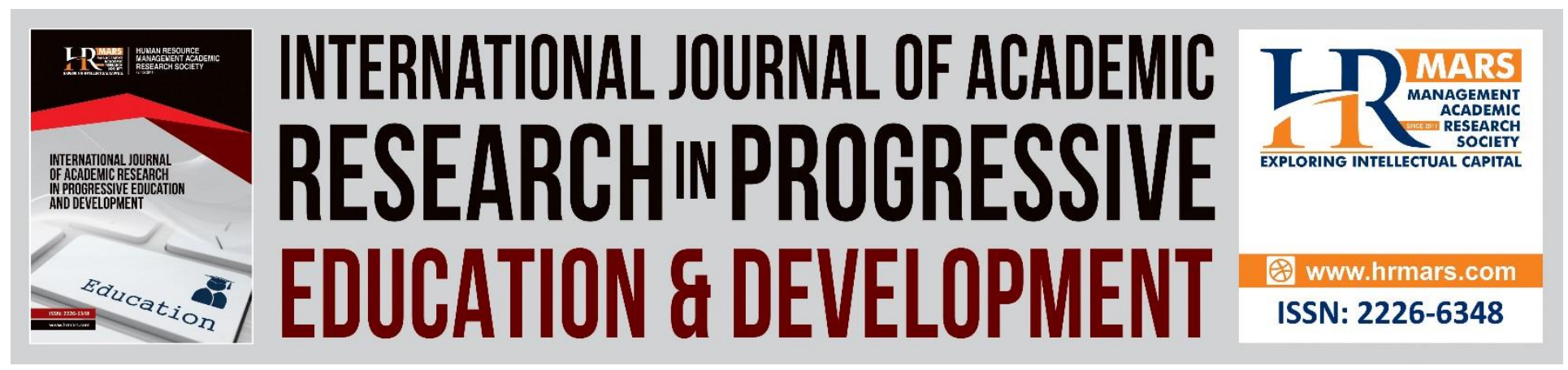

\title{
The Perceptions of Students' Experiential Learning in Relation to Theoretical Concept with Real Practice
}

Nur Asmaliza Mohd Noor, Kamisah Ariffin, Norizul Azida Darus, Asmidar Alias

To Link this Article: http://dx.doi.org/10.6007/IJARPED/v9-i4/8176

DOI:10.6007/IJARPED/v9-i4/8176

Received: 10 October 2020, Revised: 20 November 2020, Accepted: 18 December 2020

Published Online: 28 December 2020

In-Text Citation: (Noor et al., 2020)

To Cite this Article: Noor, N. A. M., Ariffin, K., Darus, N. A., \& Alias, A. (2020). The Perceptions of Students' Experiential Learning in Relation to Theoretical Concept with Real Practice. International Journal of Academic Research in Progressive Education and Development, 9(4), 25-34.

Copyright: (C) 2020 The Author(s)

Published by Human Resource Management Academic Research Society (www.hrmars.com)

This article is published under the Creative Commons Attribution (CC BY 4.0) license. Anyone may reproduce, distribute, translate and create derivative works of this article (for both commercial and non-commercial purposes), subject to full attribution to the original publication and authors. The full terms of this license may be seen

at: http://creativecommons.org/licences/by/4.0/legalcode

Vol. 9 (4) 2020, Pg. 25 - 34

http://hrmars.com/index.php/pages/detail/IJARPED

JOURNAL HOMEPAGE

Full Terms \& Conditions of access and use can be found at http://hrmars.com/index.php/pages/detail/publication-ethics 


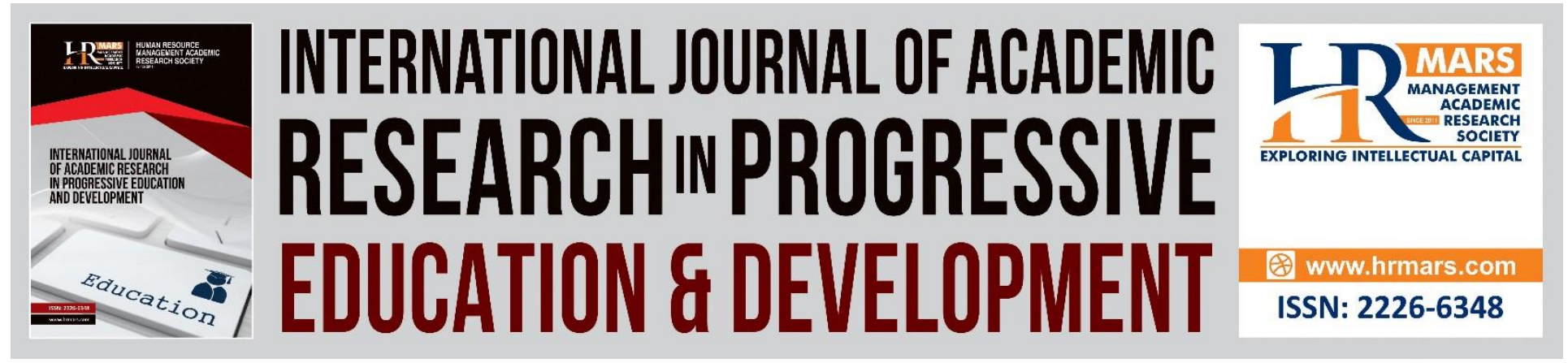

\title{
The Perceptions of Students' Experiential Learning in Relation to Theoretical Concept with Real Practice
}

\author{
Nur Asmaliza Mohd Noor ${ }^{1}$, Kamisah Ariffin², Norizul Azida Darus ${ }^{3}$, \\ Asmidar Alias ${ }^{1}$ \\ ${ }^{1}$ Faculty of Civil Engineering, Universiti Teknologi MARA Pahang, Bandar Tun Abdul Razak \\ Jengka, Pahang,Malaysia, ${ }^{2}$ Academy of Language Studies, Universiti Teknologi MARA Pahang, \\ Bandar Tun Abdul Razak Jengka, Pahang,Malaysia, ${ }^{3}$ Academy of Language Studies, Universiti \\ Teknologi MARA Perlis, 02600 Arau, Perlis, Malaysia \\ Email: nurasmaliza@uitm.edu.my
}

\begin{abstract}
By joining theoretical concept with real practice and experience, the students are able to develop their skills, knowledge and values. Thus, they are able to have the skill on problem solving, critical thinking and new experience to the new situations outside. The aim of this paper is to gauge the students' perception on the first-time experience having experiential learning in Basic Hydraulics subject. A total of 120 students were involved in this study and they were divided into two groups; conventional and experiential learning. As for experiential learning, students were requested to find solution according to the real case problem. They need to undergo the process of experiential learning in order to find the solution. Then, self-administrated questionnaires were disseminated among the students who went through the process of experiential learning to gauge their perceptions on the outcome. The results indicate that they have satisfactory results for having experience in experiential learning. They achieved meaningful learning experience through this method which required them to have full involvement along the process of problem solving.
\end{abstract}

Keywords: Real Case Problem, Students' Centered Learning, Engineering Education, Perceptions, Higher Education

\section{Introduction}

The learning process is rapidly changing over time. One of the most used learning methods in higher education is by using experiential learning. This method which required the students' involvement along the learning process, thus, increase their responsibility in learning activities is now a growing trend. Experiential learning is a method which emphasizes on the concepts, 
principles and analyzing the problem through guided practices. Hence, it is a must for students to go through the experiential learning process for their understanding in that particular subject with the supervision and guidance from the instructor/lecturer.

Instructors in the conventional engineering classrooms spend most time lecturing on the basic facts, formulae and problem-solving algorithm. This comprises of providing the course materials and giving assignments and tests to the students so as to demonstrate their ability to recite the facts. However, by using this method students are not able to explore more in the learning process. In the experiential learning process, the instructors will provide the students with the related problem and they need to know how to find the solution. The instructor/lecturer only facilitate them by giving the direction and guidance on how to solve the given problem. However, the instructor only gives formal instructions after the students already have the rough idea on what they have to do.

\section{Theoretical Consideration in Experiential Learning}

The theory of experiential learning suggests that learning is a process in which concepts are taken from the molded by experience but not an outcome. It is a continuous process which is tested by the learners' experience. It is also a process that requires the resolution of conflicts between different ways of dealing with worlds and involves contacts between the person and the environment. There are many terms which have been used to explain experiential learning such as 'learning by doing', 'experience-based learning and trial', and 'error learning' (Wolfe and Byrne, 1975). Kolb (1984) defines experiential learning as a process whereby knowledge is created through the transformation of experience. The example of experiential learning in the normal classroom is during the laboratory experiments where the students are given the framework of experiment and they have to be involved along the experiment process until they have the end results. This process allows the students to have the opportunity to explore new knowledge and new skills thus engage in pre-professional learning.

Figure 1 below was suggested by Kolb (1984) which suggests that the process of experiential learning can be described as a four-stage cycle involving four adaptive learning modes, i.e concrete experience, reflective observation, abstract conceptualization and active experimentation.

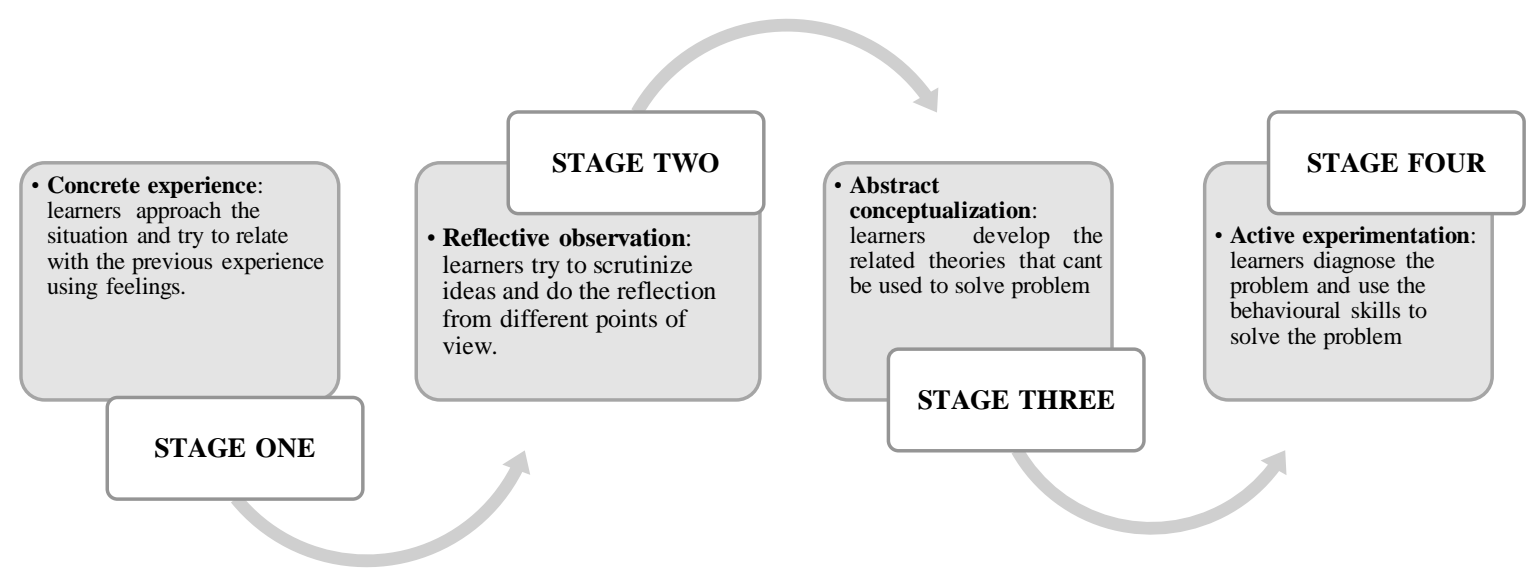

Figure 1: Stages in Experiential Learning 
INTERNATIONAL JOURNAL OF ACADEMIC RESEARCH IN PROGRESSIVE EDUCATION AND

DEVELOPMENT

Vol. 9, No. 4, 2020, E-ISSN: $2226-6348 @ 2020$ HRMARS

Hoover and Whitehead (1975) stated that the process of experiential learning not only involved with cognitive learning but need to involve all the process stated in Figure 2.

DESIGN

○
EVALUATION

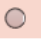

0
CONDUCT

FEEDBACK

Figure 2: The Process of Experiential Learning

Figure 2 explains that the learning process involves the four phases such as design, conduct, evaluate and feedback. The design phase is a beginning stage which requires the efforts by the instructor to establish the step for the knowledge by providing the details on the objectives of the learning, the outcome or selection of activities for participants, the identification of factors affecting student learning, the creation of a scheme for execution. This phase is crucial for the execution part of experiential learning, where by the theoretical base is laid so that the participant can view the experience in the desired context. The conduct phase involves maintaining and controlling the design. In the design phase, it may involve with the establishment of a schedule for the involvement, but in conduct phase, it involves with the changing of scheduled activities in design phase in order to suit with the learning environment. The evaluation phase emphasizes provision of opportunities for students to evaluate the experience. Participants should be able to demonstrate specific learning gained from the design and conduct of the experience. Lastly, the feedback phase is an observing process by the instructor to foster positive feedback and exclude the elements which are considered as negative feedback.

These learning process with experiments can benefit students' learning. Many scholars have noted the importance of bridging the gap between theory and practice. Bower (2013), for example, discusses an experiential learning project connected to a course in sport management curriculum. The research indicates that there are a variety of opportunities in which sport management courses and their students can take part in as part of experiential learning. Along the same line, Judge et al. (2011) demonstrates experiential learning programme carried out by a sport lessons about event management that gives students hands-on experience that transfers to other professional opportunities in sport management. In the same vein, Hawtrey's (2007) study indicates that students prefer experiential learning process as it encourages their motivation and better retention of knowledge compared to the conventional approach. Thus, experiential learning can be effective in teaching because it can encourage the students' engagement in the process of learning. Students need to discuss among their peers about the respective topic, apply the theoretical knowledge in order to setup the experiment as well as to solve real given problem and make use of given material by the instructors.

\section{Malaysia Experience in Experiential Learning}

In Malaysia, the normal practice of teaching engineering classroom is more to the conventional method, where lecturers spend a great deal of class time lecturing on the basic facts, formulas, algorithm that comprises the course material, as well as giving assignments and tests to the 
students to demonstrate their ability to recite the facts. Hence, such approach does not encourage students to participate much in the process of teaching and learning in the classroom.

New approaches of teaching such as experiential learning have been introduced in order to increase the employability rate among engineering students thus align with the new inspiration of education in Malaysia. The early approach using experiential learning activities in Malaysia Education has been introduced in 2009 (Tahir et al., 2009) with the target to provide and prepare the students with hands-on and real case study problem. This seems to be agreed with the finding through a study on the graduated students from public university having good academic and facilitates with experiential learning approach and able to produce students who work readiness (Johan, 2015). Besides, instructors should provide practical troubleshooting methods or drill exercises in order to accommodate the learning preference for active learners (Martinez Cartas, 2012).

\section{Basic Hydraulic Subject Experience in Experiential Learning}

The Basic Hydraulic Engineering is a course deals with water flow in typical civil engineering applications which involved with flow in pipelines, pipe network, uniform and non-uniform flow in open channels and fluid machineries. There are three outcomes that need to be achieved by the student, i) solve engineering problems in pipes and pipe network, ii) evaluate the flow in open channels, iii) analyses the pumps and turbines.

Since to the date, there is no study conducted on the implementation of experiential learning in the Hydraulic Engineering course. Thus, the objective of this paper is to gauge the students' perception at the effectiveness of experiential learning under Basic Hydraulic Subject.

\section{Data Collection \& Data Analysis}

120 students ( 68 males and 52 females) were involved in this study, received the experiential assignment and they were divided into two groups; first group (60 students) involved with the implementation of experiential learning in the learning process while the second group (60 students) went through the conventional learning process. The theoretical part had been taught earlier by the instructor. For conventional method, they received real case problem on open channel and need to solve based their own justification while as for experiential learning group, they have to go through two phases of learning process. The first phase involved with the implementation of experiential learning approach where students were required to find solution for a given problem on open channel. They were required to form a group of 4 members, and they need to identify the parameters need to be measured. They had to conduct the process such as measurement and calculation to solve the problems. Then, both groups (conventional and experiential) had to share their findings as part of assignment marks. The second phase is to gauge the students' perception at the effectiveness of experiential gaining knowledge of technique in getting to know through a self-completed survey questionnaire with four-point Likert scale. The survey was carried out right after the completion of the project and the statements were related to the learning content and learning progress that they have been through along the experiential learning process. Then, the data were analyzed using simple frequency counts and the composite score was determined by using total score in SPSS. 


\section{Results \& Discussion}

Figure 3 shows the final grade obtained by the students who went through the conventional and experiential methods. Based on the results, it was found that $10 \%$ which is 6 out of 60 students who sat for experiential learning scored grade A, A-. On the other hand, the results from the traditional method students indicated that $15 \%$ which is 9 out 0 f 60 students scored a low grade, C-. In a study conducted by Bolong et.al. (2014) to access the effects of open-ended lab towards the learners' performance specified that the open-ended laboratory method produced a better result compared to the conventional method. This demonstrate that the weaker students also will benefit from this method by understanding the task and enable them to increase their understanding (Haron et al. 2013; Chiu and Chiu, 2004)

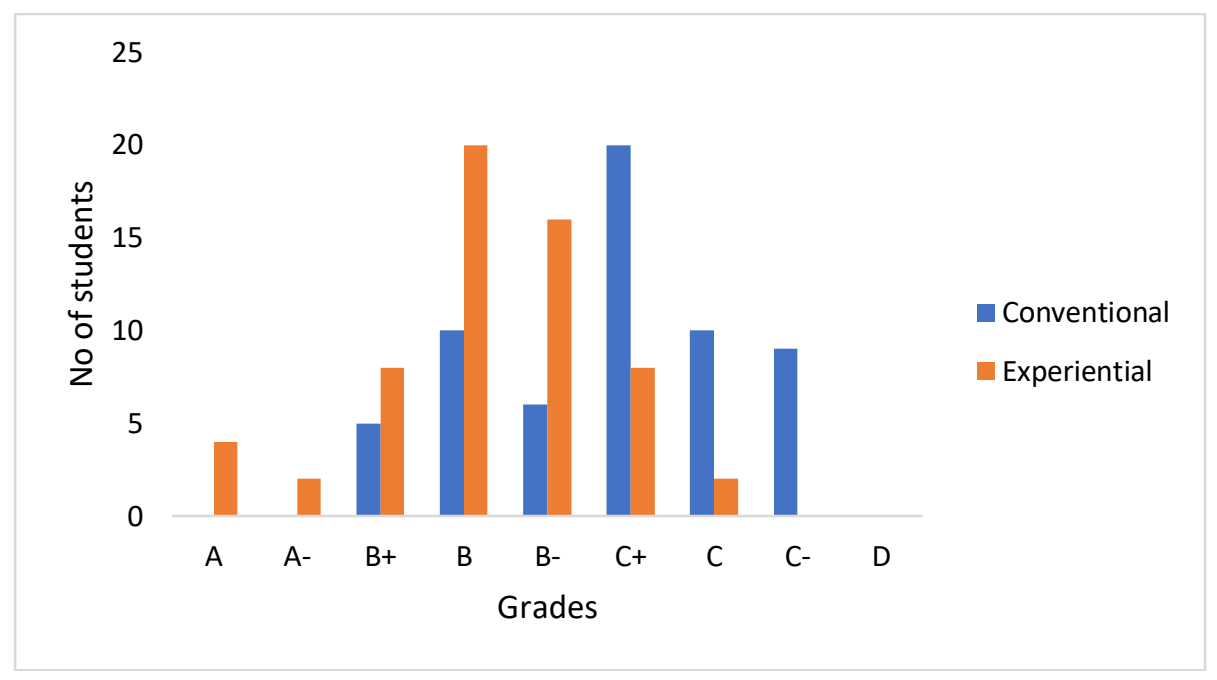

Figure 3: Grade obtained by students through conventional and experiential method

Overall, the implementation of experiential learning received the overwhelming response from the students as they felt that through this approach has made them understand better compared to the conventional approach. They also believed that the experiential learning activities had contributed towards enriching their learning experience.

Table 1 clearly showed the positive response from the respondents with regard to learning context through experiential learning. 
INTERNATIONAL JOURNAL OF ACADEMIC RESEARCH IN PROGRESSIVE EDUCATION AND DEVELOPMENT

Vol. 9, No. 4, 2020, E-ISSN: $2226-6348$ @ 2020 HRMARS

Table 1: Learning Content through Experiential Learning

\begin{tabular}{|c|c|c|}
\hline No & Statement & Mean \\
\hline 1 & I am interested in the subject of practical learning. & $\begin{array}{l}3.4872 \pm \\
0.50637\end{array}$ \\
\hline 2 & I feel good about practical learning inside the classroom. & $3.1538 \pm 0.62989$ \\
\hline 3 & Experiential learning experience helps to develop my skill. & $3.5128 \pm 0.50637$ \\
\hline 4 & $\begin{array}{l}\text { This activity has provided me with a direct practical experience to } \\
\text { help understand the course concepts. }\end{array}$ & $3.5385 \pm 0.50504$ \\
\hline 5 & $\begin{array}{l}\text { This activity has given me a concrete experience that helps me } \\
\text { learn the course. }\end{array}$ & $3.4872 \pm 0.50637$ \\
\hline 6 & $\begin{array}{l}\text { This activity has presented me with a "real world" experience } \\
\text { related to this course. }\end{array}$ & $3.5897 \pm 0.54858$ \\
\hline 7 & $\begin{array}{l}\text { This activity has helped me relate my personal experiences to the } \\
\text { content of this course. }\end{array}$ & $3.3590 \pm 0.53740$ \\
\hline 8 & $\begin{array}{l}\text { This activity has shown me how the class concepts are inter- } \\
\text { related. }\end{array}$ & $3.4615 \pm 0.50504$ \\
\hline 9 & $\begin{array}{l}\text { This activity has helped develop my ability to identify, formulate } \\
\text { and solve engineering problems using thinking skills }\end{array}$ & $3.4103 \pm 0.49831$ \\
\hline 10 & $\begin{array}{l}\text { This activity has allowed me to experiment with the course } \\
\text { concepts in order to understand them. }\end{array}$ & $3.5128 \pm 0.50637$ \\
\hline 11 & This activity is interesting once I get into it. & $3.6154 \pm 0.54364$ \\
\hline
\end{tabular}

The finding specifies that majority of the students were interested in this activity (mean score $=3.4872 \pm 0.50637$ ) because they were able to develop their practical skill (mean score $=3.5128 \pm$ 0.50637). They also believed that experiential learning activities could help them understand the content of the course (mean score=3.5385 \pm 0.50504). The students also agreed that by conducting all the activities such as doing the measurement of the nearby drainage, they felt they had gone through the real-world experience (mean score $=3.5897 \pm 0.54858$ ) and definitely they really enjoyed doing those activities (mean score $=3.6154 \pm 0.54364$ ). Meanwhile, Table 2 indicate the learning progress that the students received through experiential learning. The response also is quite promising as they stated that they gained an enhancement of their knowledge (mean score $=3.1795 \pm 0.45142$ ), thus showed the progression occurred in this learning activities. They are also aware that through experiential learning, the development of skills has shown the positive progress (mean score $=3.2564 \pm 0.49831$ ), increase ability on how to apply the material in order to solve the given problem (mean score $=3.1026 \pm 0.38353$ ) and increase the desire to learn more about the subject (mean score=3.3590 \pm 0.53740 ). 
INTERNATIONAL JOURNAL OF ACADEMIC RESEARCH IN PROGRESSIVE EDUCATION AND DEVELOPMENT

Vol. 9, No. 4, 2020, E-ISSN: $2226-6348 @ 2020$ HRMARS

Table 2: Students' Learning Progress through Experiential Learning

\begin{tabular}{|l|l|l|}
\hline No & Statement & Mean \\
\hline $\mathbf{1}$ & I have gained knowledge through this activity & $\begin{array}{l}3.1795 \pm 0 \\
.45142\end{array}$ \\
\hline $\mathbf{2}$ & I have developed skills through this activity & $3.2564 \pm 0.49831$ \\
\hline $\mathbf{3}$ & I have expanded my effort through this activity & $3.1282 \pm 0.46901$ \\
\hline $\mathbf{4}$ & I have the ability to apply the learning materials in this activity. & $3.1026 \pm 0.38353$ \\
\hline $\mathbf{5}$ & I have the desire to learn more about this subject & $3.3590 \pm 0.53740$ \\
\hline
\end{tabular}

From the previous study by Atousa (2017), students found the interesting learning process with experiential learning and they look forward to have more experiential learning approaches in other courses. Students also has rated good on the understanding of the subject which went through the experiential learning process compared to the traditional approach. The students also felt good as they have better explanation and understanding when they went through the practice experience in the subject (Gil et al., 2009). Furthermore, the effectiveness of applying the experiential learning theory has been conducted among the students and the responses are very good where the mean satisfactory rate with the quality of the course has increased to a level with $67.7 \%$ of the students and it can be considered as satisfactory (Li et al., 2017).

\section{Successful Factors of Experiential Learning}

There were many factors which contribute to the success of experiential learning research since most of the learning outcomes and essential components of experiential learning were met.

\section{Component 1: Experience}

Through experiential learning, most of students agreed that they have gained meaningful experiences and this has achieved the target of experiential learning which is to get the students involved in something personally significant and meaningful to them.

\section{Component 2: Engagement}

Most students agreed that through this activity, it gave them a strong sense of ownership to the assignment and their level of understanding and commitment were much higher than just acquiring knowledge in a lecture. They have to discuss the plan and theory prior starting the assignment.

Component 3: Whole-person Involvement

Experiential learning gave a chance to reinforce the experience for the students involved in the study. The remarkable memories may help them to retain the lesson longer compared to the traditional method

\section{Conclusion}

In a nut shell, this study has shown that students who went through the experiential learning method scored better grades, where $10 \%$ of these students obtained A and A-grades compared to the conventional learning method. The students agreed that the experiential activities have 
created an interesting learning process and provided them a real-world experience, thus, enabled them to relate to what they learned in class. As indicated by the survey, the students' response towards the implementation of experiential learning activities in engineering subjects has been overwhelmingly positive. With the benefits of these activities on the students' development in learning, it is hoped that experiential learning is formally included as one of the delivery methods in the syllabus.

\section{References}

Atousa, H. (2017). Incorporating experiential learning in engineering courses. IEEE communications Magazine, November 2017.

Bolong, N., Jodin, M., and Saad, I. (2014). Effect of Open Ended Laboratory towards Learners Performance in Environmental Engineering Courses: Case Study of Civil Engineering at University Malaysia Sabah. International Journal of Educational and Pedagogical Sciences 8(8): 2562-2566.

Bower, G. G. (2013). Utilizing Kolb's experiential learning theory to implement a golf scramble. International Journal of Sport Management, Recreation and Tourism 12: 29-56.

Chiu, M. D., and Chiu, S. Y. (2004). An Open Ended Laboratory System with Computer Aided Simulation for Undergraduate Electronic Engineering. International Journal of Engineering Education 2(20): 193-197.

Gil, R., Donald, C. G., and Alain, W. (2009). Experiential Learning Approach for Requirements Engineering Education. Requirements Engineering 14 (4): 269-287.

Haron, Z., Mohammad, S., Sam, M. A. R. Mustaffar, M., and Yatim, M. J. (2013). The implementation of an open ended experiment in the civil engineering laboratory. Procediasocial and behavioral Sciences 102: 548-559.

Hawtrey, K. (2007). Using experiential learning techniques. Journal of Economic Education 38: 143-152.

Hoover, J. D., and Whitehead, C. J. (1975). An experiential cognitive methodology in the first course in management: some preliminary results. Simulation Games and Experiential Learning in Action 2.

Johan, K. (2015). Perception of Students Towards Lecturers Teaching Engineering Courses with Industry Experience: A Case Study in Malaysia Technical University. Procedia - Social and Behavioral Sciences 195: 925 - 931.

Judge, L. W., Pierce, D., Petersen, J., Bellar, D., Wanless, E., and Gilreath, E. (2011). Engaging experiential service learning through a co-curricular club: the Chase Charlie Races. Journal of Research 6(2): 30-38

Kolb, D. A. (1984). Experiential learning: experience as the source of learning and development Englewood Cliffs, NJ: Prentice-Hall.

Li, H., Andreas, O., and Wayne, H. (2017). Application of experiential learning to improve students' engagement and experiences in a Mechanical Engineering Courses. European Journal of Engineering Education: 1-11.

Martínez Cartas, M. L. (2012). Using an improved virtual learning environment for engineering students. European Journal of Engineering Education, 37(3): 229-241. doi:10.1080/03043797.2012.678985 
INTERNATIONAL JOURNAL OF ACADEMIC RESEARCH IN PROGRESSIVE EDUCATION AND DEVELOPMENT

Vol. 9, No. 4, 2020, E-ISSN: 2226-6348 @ 2020 HRMARS

Tahir, M., Abdullah, N., Usman, I., Che-Ani, A. Nor, M. F. I. M., and Surat, M. (2009). Constructing place and space in the design of learning environments for PBL in Malaysian universities. AJTLHE: ASEAN Journal of Teaching and Learning in Higher Education 1(1): 26-34.

Wolfe, D. E., and Byrne, E. T. (1975). Research on experiential learning: Enhancing the process. Business Games and Experiential Learning in Action 2: 325- 336. 